\title{
Influence of destination attributes on destination image of Surabaya City according to domestic MICE participants
}

\author{
Fitri Novika Widjaja \\ University of Surabaya, Surabaya, Indonesia
}

\begin{abstract}
This study aims to determine the influence of destination attributes on destination image of Surabaya city according to the domestic MICE participants and also to know the differences in perception concerning the importance of MICE destination attributes based on socio-demographic characteristics of respondents. The study used questionnaire distribution using judgmental sampling technique. The data were processed by multiple regression method to see the influence of destination attributes towards destination images and ANOVA t-test to test the differences in perception. The results indicated that destination attributes have a significant positive influence on the destination image formation of Surabaya City, especially in the attributes of Amenities, Accountability, and Attraction. While the difference when viewed from Cognitive Image and Affective Image test results shows that there are differences in perception among MICE participants on the importance of destination attributes in forming the image of a MICE city.
\end{abstract}

Keywords: destination attributes, destination image, MICE

\section{INTRODUCTION}

The development of MICE industry (Meeting, Incentive, Conferencing and Exhibition) gives an economic impact for the region of MICE organizer (Murdopo 2011). MICE tourism has been described as a new segment of tourism industry; a new type of tourism arising out of the increase in number of conventions and exhibitions (Kesrul 2004). Destination image is a critical factor in travel decisions. Concept of destination image as Crompton (1979) define image as the sum of beliefs, ideas, and impressions the person has about a destination. Echtner \& Richie (1993) described destination image as perception of an area.

Surabaya is the second biggest city in after Jakarta city, where today the Surabaya city government continues its efforts to make Surabaya as a competitive MICE tourism destination outside Jakarta and Bali. As a MICE destination, Surabaya is entailed to have facilities such as meeting rooms, ballrooms and hotels as well as pull factors that can influence a person's decision to attend or participate in a MICE activity. In Surabaya, tourism is a growing sector, and the Surabaya city government is constantly striving to develop it as seen with the construction of an international convention hall in Surabaya. According to Gito Sugiarto (General Manager of Jakarta International Expo, who also manages the project in East Java), the exhibition industry is growing $10-20 \%$ per year, plus the rapid development of industry in surrounding cities (including Rp 2 trillion investments to develop the Madura Island economy after the operation of Suramadu Bridge) making Surabaya ready to become an international exhibition destination.

Increase in new hotel construction in Surabaya also shows that demand for MICE activities using hotel facilities such as meeting rooms and various events are increasing. About $60 \%$ of hotel revenues are obtained from MICE activities through renting hotel facilities (www.kabarbisnis.com).

Surabaya also operates a variety of tourist attractions, such as natural attractions, historical tours, and cultural tourism. There are more than 150 tourist attractions in Surabaya City, 24 nature tourism and entertainments, 69 historical and religious tours as well as more than 58 shopping-culinary tours. The availability of various tourist attractions indicates that $\mathrm{Su}-$ rabaya as a MICE destination city has its own attraction for MICE participants as in addition to attending MICE activities; they can also visit tourist attractions once they finish their MICE activities.

Lim \& Omar (2012) study on the influence of destination attributes on image formation done in 
Jordan city, show the positive influence of destination attribute availability in forming Jordan city as MICE destination city. Martin \& Rodriguez (2008) studies the aspects of cognitive image and affective image in the formation of destination image from psychological factors showed that MICE participants' perceptions can be formed by two different factors. Matos et al. (2012) said about revisiting the destination image construct through a conceptual model.

Considering various attributes in Surabaya city as a means of MICE tourism which allegedly can form destination image for every MICE participant, thus it is necessary to study the influence of destination attributes on destination image of Surabaya city according to MICE participants.

\section{RESEARCH METHODS}

The type of research used was causal research. Data were obtained by distributing questionnaires directly to respondents who attended a MICE activity in Surabaya in 2016-2017. The distributed questionnaire consisted of three parts. The first part contained general questions about the characteristics of the respondents. The second part asked questions about destination attributes using scale 1 (very unimportant) to 5 (very important). The third part contained questions regarding destination images using scale 1 (strongly disagree) to 5 (strongly agree).

Characteristics of the population in this study were MICE participants from Indonesia and domiciled in a city in Indonesia who attended MICE activities with more than 24-hour duration in Surabaya in 2016-2017 with the minimum education level of high school or equivalent. The attended MICE activities could be a meeting, incentive, conference, or exhibition or a combination of these four activities. The sample in this study used non-probability sampling because the population studied was not identified in number (Sugiyono 2013). The sample size used in this research was minimum 150 persons. These numbers were using the concept proposed by Hair et al. (2010) as a reference that says the sample size for multiple regression research is at least 50, and the more will give better results. Data processing in this study used ANOVA, t-test, and multiple regressions. The hypotheses to be tested in this study were the followings:

$\mathrm{HO}_{\mathrm{a}}$ : Destination attributes of MICE tourism have no positive influence on the formation of destination image of Surabaya City.

$\mathrm{H} 1_{\mathrm{a}}$ : Destination attributes of MICE tourism have a positive influence on the formation of destination image of Surabaya City.
$\mathrm{H} 0_{\mathrm{b}}$ : There are no differences in perception among MICE participants in Surabaya concerning the importance of MICE destination attributes based on socio-demographic characteristics such as hometown, gender, age, and education level.

$\mathrm{H} 1_{\mathrm{b}}$ : There are differences in perception among MICE participants in Surabaya concerning the importance of MICE destination attributes based on socio-demographic characteristics such as gender, age, and education level.

\section{RESULT AND DISCUSSION}

The initial stage of the study conducted data collection of 30 samples then tested the validity and reliability. The results obtained were statements for all dimensions of destination attributes, and destination images are considered valid because the loading factor value is greater than 0.5 . The reliability testing to measure destination attribute and destination images can be said to be reliable because all Cronbach's alpha values are greater than 0.6. After that, it will proceed to distribute the questionnaire to reach 200 samples.

Table 1. Multiple regression analysis destination attributes of MICE on destination image of Surabaya City

\begin{tabular}{llcl}
\hline Destination & \multicolumn{3}{c}{ Overall Image } \\
Attributes of MICE & $\beta$ & $\mathrm{t}$ & $\mathrm{p}$ \\
\hline Amenities (A-1) & 0.23 & 2.96 & 0.00 \\
Accessibility (A-2) & 0.02 & 1.01 & 0.13 \\
Accountability (A-3) & 0.33 & 2.29 & 0.02 \\
Affordability (A-4) & 0.12 & 4.03 & 0.20 \\
$\mathrm{R}^{2}$ & & 0.46 & \\
$\mathrm{~F}$ & & 26.86 & \\
$\mathrm{p}$ & & 0.00 & \\
*** Significance level at 1\%, ** Significance level at 5\%.
\end{tabular}

Table 2. Multiple regressions on the aspects of cognitive image and affective image

\begin{tabular}{lllllll}
\hline & A-1 & A-2 & A-3 & A-4 & A-5 & A-6 \\
\hline Male & 4.03 & 4.50 & 3.77 & 3.77 & 3.42 & 3.69 \\
Female & 3.86 & 4.08 & 4.11 & 3.79 & 4.79 & 3.22 \\
Difference & 0.18 & 0.43 & -0.35 & -0.02 & -1.37 & 0.47 \\
in Mean & & & & & & \\
t & 2.01 & 4.03 & -4.28 & -1.09 & -8.55 & 3.25 \\
Sig. & 0.02 & 0.00 & 0.00 & 0.38 & 0.00 & 0.01 \\
\hline
\end{tabular}

*** Significance level at 1\%, ** Significance level at 5\%,

Multiple linear regression analysis shows that MICE destination attributes affect destination image of Surabaya city. This can be seen from the $p$ value of 0.00 . The attributes of the amenities, accountability and attraction proved to influence the formation of positive image of Surabaya city as a MICE city. The availability of hotel, meeting hall, and exhibition hall in Surabaya city can be perceived as MICE activity facilities. In addition, the availability of ade- 
quate facilities and easy access to transportation facilities such as airports, stations and terminals are also perceived to support the implementation of MICE activities in Surabaya. Another attraction is the availability of shopping centers, a variety of local culinary options, and local performances as typical tourist attractions of Surabaya.

In the aspect of the cognitive image, it is seen that the six destination attributes influence destination image of Surabaya city as a MICE city except for accountability attribute. These results indicate that external stimuli such as the availability of hotels, restaurants, meeting rooms, various tourist attractions, city cleanliness, infrastructures, and the condition of Surabaya people can form the image of Surabaya as the city for MICE activities. While in the affective image aspect, only the attributes of accountability and attraction proven to have an effect on destination image. The result of regression test above shows that $\mathrm{H} 1_{\mathrm{a}}$ hypothesis can be accepted meaning: destination attributes from MICE tourism have positive influence on the destination image formation of Surabaya city.

Table 3. Differences in perception of MICE participant's destination attributes based on gender

\begin{tabular}{lrrrrrr}
\hline $\begin{array}{l}\text { Destination } \\
\text { Attributes } \\
\text { of MICE }\end{array}$ & \multicolumn{3}{c}{ Cognitive Image } & \multicolumn{3}{c}{ Affective Image } \\
& & & & & & \\
& $\beta$ & $\mathrm{t}$ & $\mathrm{p}$ & $\beta$ & $\mathrm{t}$ & $\mathrm{p}$ \\
\hline $\mathrm{A}-1$ & 0.17 & 3.76 & 0.02 & 0.05 & 0.90 & 0.21 \\
$\mathrm{~A}-2$ & 0.30 & 5.35 & 0.01 & 0.10 & 0.84 & 0.38 \\
$\mathrm{~A}-3$ & 0.05 & 0.82 & 0.33 & 0.62 & -3.71 & 0.04 \\
$\mathrm{~A}-4$ & 0.41 & 2.10 & 0.03 & 0.02 & 1.44 & 0.16 \\
$\mathrm{~A}-5$ & 0.22 & 4.45 & 0.00 & 0.42 & 3.67 & 0.00 \\
$\mathrm{~A}-6$ & 0.62 & 2.67 & 0.03 & 0.04 & 0.67 & 0.42 \\
$\mathrm{R}$ & & 0.51 & & & 0.38 & \\
$\mathrm{~F}$ & & 32.46 & & & 20.64 & \\
$\mathrm{P}$ & & 0.00 & & & 0.00 & \\
\hline
\end{tabular}

*** Significance level at $1 \%, * *$ Significance level at 5\%,

In differences in perception test between male and female MICE participants on destination attributes, it is proven that there are differences in perception on all attributes except on affordability attribute. This shows that male participants have more positive perception than female participants in the attributes of amenities, accessibility and activities. Meanwhile, female participants have a more positive perception on the attributes of accountability and attraction.

Differences in perception of MICE participants towards destination attributes when viewed by age shows that there are significant differences in the attributes of amenities, accountability, affordability and attraction. The age of 31 years or older tends to have a more positive perception but in the attribute of attraction, the age of 30 years or younger has more positive perception that Surabaya city manages attractions such as shopping, local culinary and local performances than other age group. While the attributes of accessibility and activities test results show no differences in perception of MICE participants in all age groups

Table 4. Differences in perception of MICE participant's destination attributes based on age

\begin{tabular}{lllllll}
\hline $\begin{array}{l}\text { Age } \\
\text { Group }\end{array}$ & A-1 & A-2 & A-3 & A-4 & A-5 & A-6 \\
\hline$<30$ & 3.53 & 4.07 & 3.73 & 3.84 & 3.92 & 3.30 \\
$31-40$ & 3.90 & 4.16 & 3.65 & 3.90 & 3.85 & 3.41 \\
$41-50$ & 4.13 & 4.02 & 4.19 & 3.97 & 3.79 & 3.47 \\
$51-60$ & 4.08 & 4.10 & 3.98 & 3.47 & 3.12 & 3.47 \\
F & 7.19 & 1.86 & 6.76 & 4.08 & 4.26 & 1.78 \\
Sig. & 0.00 & 0.32 & 0.00 & 0.04 & 0.01 & 0.50 \\
\hline
\end{tabular}

*** Significance level at $1 \%$, ** Significance level at 5\%,

Table 5 shows the differences in perceptions of MICE participants testing based on education level indicate that there were significant differences in perception on the attributes of the amenities, amenities, accessibility, attraction, and activities. While the attributes of accountability and affordability showed no differences in perception of MICE participants towards destination attribute. The undergraduate education level shows the most positive perception of the attributes of amenities, accessibility, attraction, and activities, while the postgraduate degree has the highest perception on accountability and affordability attributes.

Table 5. Differences in perception of MICE participant's destination attributes based on education level

\begin{tabular}{lcccccc}
\hline $\begin{array}{l}\text { Education } \\
\text { Level }\end{array}$ & A-1 & A-2 & A-3 & A-4 & A-5 & A-6 \\
\hline $\begin{array}{l}\text { High school } \\
\text { Diploma }\end{array}$ & 4.13 & 4.10 & 4.15 & 3.88 & 4.05 & 3.77 \\
$\begin{array}{l}\text { Under- } \\
\text { Graduate }\end{array}$ & 4.47 & 4.34 & 4.04 & 3.90 & 4.43 & 3.50 \\
$\begin{array}{l}\text { Post- } \\
\text { Graduate }\end{array}$ & 4.32 & 4.28 & 4.11 & 3.98 & 4.37 & 3.68 \\
Doctorate & 4.03 & 4.01 & 4.01 & 3.80 & 4.12 & 3.48 \\
F & 9.64 & 5.81 & 1.73 & 2.05 & 3.76 & 2.59 \\
Sig. & 0.00 & 0.00 & 0.28 & 0.08 & 0.02 & 0.04 \\
\hline$* * *$ Significance level at $1 \%$ & $* *$ Significance level at 5\%
\end{tabular}

** Significance level at $1 \%$, ** Significance level at $5 \%$,

Based on these results, it can be said that $\mathrm{H} 1_{\mathrm{b}}$ hypothesis is accepted, meaning there is differences in perception among MICE participants related to the importance of MICE destination attributes based on socio-demographic characteristics such as gender, age, and education level.

\section{CONCLUSION}

The research results show that the destination attributes of MICE tourism proved to have a significant positive influence on the formation of destination image of Surabaya city. Attributes that are proven to 
have influence are the amenities, accountability and attraction. When viewed from psychological factors, then there are different results related to cognitive image and affective image. The domestic MICE participants who participated in Surabaya city MICE activities saw more external stimuli such as the availability of the event, road access, the choice of tourist attraction, the cleanliness of the city, the security and social condition of Surabaya city.

The results also show that there are differences in perception among MICE participants related to the importance of MICE destination attributes based on socio-demographic characteristics such as gender, age, and education level. The results of this study support the previous Lim \& Omar (2012) study on the influence of destination attributes on destination image formation in Jordan city.

Recommendations for future research are on destination image measurements. We recommend that the measurement of destination images should not only use two components of the cognitive image and affective image but also the complex image component as Crompton (1991) in Lim \& Omar (2012). The complex image can measure destination image on the basis of the actual experience that MICE participants experienced during their stay because the experience will form the perception of the place.

\section{REFERENCES}

Crompton, J.L. 1979. An assessment of the image of Mexico as a vacation destination and the influence of geographical location upon the image. Journal of Travel Research 17(4): 18-23.

Echtner, C.M. \& Ritchie, J.R.B. 1993. The meaning and measurement of destination Image. Journal of Tourism Studies 14(1): 37-48.

Hair, J.F. 2010, Multivariate Data Analysis $7^{\text {th }}$ Edition. New Jersey: Prentice Hall Inc.

Kesrul, M. 2004. Meeting, Incentive Trip, Conference, Exhibition. Yogyakarta: Graha Ilmu

Lim, K.C. \& Omar. A. 2012. The role of destination attributes on forming jordan touristic image. SAVAF International 3: 267-277.

Martin, H.S. \& Rodriguez, I.A. 2008. Exploring the cognitiveaffective nature of destination image and the role of psychological factors in its formation. Tourism Management 29: 263-277.

Matos, N., J. Mondes., \& Valle, P. 2012. Revisiting the destination image construct through a conceptual model. A Multidisciplinary e-journal 21: 105.

Murdopo. 2011. Potensi Industri MICE Indonesia. Warta Ekspor: $1-9$.

Sugiyono. 2013. Statistika untuk Penelitian. Bandung: Alfabeta. 